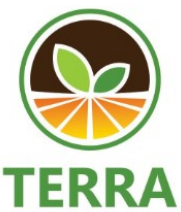

Journal of Land Restoration

\title{
Application of Vermicompost to Soil P Levels, Tissue P Levels, and Corn Yields in Entisols
}

\author{
Efian Aprizal ${ }^{1}$, Hasanudin ${ }^{1 *}$, R.R Yudhi Harini Bertham ${ }^{1}$, Herry Gusmara ${ }^{1}$, Edhi Turmudi ${ }^{2}$ \\ ${ }^{1}$ Soil Science Department University of Bengkulu, Bengkulu, 38121, Indonesia \\ ${ }^{2}$ Agroecotechnology Department, University of Bengkulu, Bengkulu, 38121, Indonesia
}

email : hasanudin@unib.ac.id

\begin{abstract}
This study aims to determine the optimum dossage of vermicompost to soil P levels, tissue P levels as well as corn growth and yield in Entisols. This research was conducted at Kandang Mas village, Bengkulu City from August 2019 until November 2019. The design used in this study is Randomized Complete Block Design (RCBD) one factor is the application of vermicompost dose with three replications. The dossage of vermicompost consists of seven levels, namely 0 tons ha $a^{-1}, 5$ tons ha $a^{-1}, 10$ tons ha $a^{-1}, 15$ tons ha $a^{-1}, 20$ tons ha $a^{-1}, 25$ tons hal ${ }^{-1}$, and 30 tons ha $a^{-1}$. The results showed that there was no optimum dossage of vermicompost to soil P levels, tissue P levels, and corn yield in Entisols.
\end{abstract}

Keywords : : Entisols, corn, P levels, vermicompost

\section{INTRODUCTION}

Indonesia has an area of about 188.2 million ha and about $50 \%$ classified as potential land for agriculture. The area suitable for the development of dryland food crops is estimated to reach an area of 25.09 million ha. Dryland that is wide and potential to be used as an agricultural area for example is Entisols land that has an area of 70.5 million ha (Pusat Penelitian Tanah dan Agroklimat, 2000) spread across various major islands in Indonesia, one of which is in Bengkulu Province.

The considerable potential of Entisols land in Bengkulu Province is followed by various problems and limitations. Entisols soil has low organic matter, $\mathrm{P}$ availability, low micro and CEC nutrients as well as soil saturation, Aluminum Saturation (Al), iron saturation (Fe), and high manganese saturation (Mn) to poison plants (Mulyani, 2010). The provision of vermicompost fertilizer is expected to fix the problems in Entisols.

Vermicompost is a fertilizer composting organic waste with the help of earthworms that can fertilize the soil (Kusnadi, 2000) Vermicompost fertilizer can bind water and soil nutrients higher than other compost fertilizers. The enzyme content in vermicompost helps in the process of nutrient synthesis so that it can be directly absorbed by plants. Soil microbial content in vermicompost is useful, improving soil and plant health, also a source of nutrients for soil microbes (Mashur, 2001).

Mulat (2005) states that the content of nutrients in the soil such as $\mathrm{N}, \mathrm{P}_{2} \mathrm{O}_{5}, \mathrm{~K}_{2} \mathrm{O}, \mathrm{CaO}, \mathrm{MgO}$, and $\mathrm{Mn}$ is the highest by administration of Vermicompost compared to chicken manure, biogas sludge, and compost. The high availability of macro and microelements in vermicompost is due to the composting process carried out in the body of worms.

Based on the results of some studies showed that the treatment of the administration of vermicompost fertilizer can increase the availability of nutrients in the soil and further to some extent can increase the absorption of nutrients carried out by plants. The results of the study (Riwandi 2013) showed that the increase in the administration of compost fertilizer at a dose of 22.50 tons ha ${ }^{-1}$ can increase the content of $\mathrm{C}$ and $\mathrm{N}$ in the soil by $0.14 \%$ and $0.03 \%$ respectively. Increased nutrient content in the soil can increase the concentration of absorption of $\mathrm{N}, \mathrm{P}$, and $\mathrm{K}$ plants. The concentration of $\mathrm{N}$, $\mathrm{P}$, and $\mathrm{K}$ in the leaves increased by administering a dose of compost fertilizer of 22.50 tons $\mathrm{ha}^{-1}$ respectively $1.68 \%, 0.13 \%$, and $1.59 \%$. In this study, the plant used was Bisi 2 corn. 
Corn is the main commodity in Indonesia because in addition to human food raw materials are also a source of animal feed and other industrial materials (Kurniati, 2012). The demand for corn increased year after year in line with the increasing demand for food, feed, and industry. Domestic corn needs for feed reached 4.9 million tons in 2005 and is predicted to be 6.6 million tons in 2010 (Ditjen Tanaman Pangan, 2006). Export opportunities are also increasing as corn-producing countries such as America, Argentina, and China begin to limit their export volume due to increased domestic needs (Hadijah, 2009).

Corn occupies a key position as one of the most important cereals for human and animal consumption, not only in the form of food products but also in other derivative products. This plant grows in a variety of conditions in different parts of the world (Idris \& Ali, 2015). The advantage of corn over other food commodities is its nutritional content is higher than rice. Indonesian resources are also very supportive for its cultivation, the price is relatively cheap, and the availability of cultivation technology to processing (Purwono \&Hartono, 2006).

The survival of corn crops requires 16 nutrients. Three essential nutrients, carbon, hydrogen, and oxygen, are taken from the air and water in the form of $\mathrm{CO}_{2}, \mathrm{H}_{2} \mathrm{O}$, and $\mathrm{O}_{2}$. Primary nutrients namely $\mathrm{N}, \mathrm{P}$, and $\mathrm{K}$ are nutrients needed by plants in relatively large quantities compared to other nutrients. Secondary nutrients namely calcium, magnesium, and sulfur are relatively fewer nutrients needed by plants compared to the main nutrients. Primary and secondary nutrients are often referred to as macro.copper, boron, and molybdenum nutrients are required relatively less than secondary nutrients (Mori 1999). The above nutrient needs can be met by giving vermicompost fertilizer.

This study aims to determine the optimum dose of vermicompost against soil $\mathrm{P}$ levels, tissue $\mathrm{P}$ levels as well as corn yield in Entisols.

\section{MATERIALS AND METHODS}

This research was conducted in Kandang Mas village, Bengkulu City from August 2019 until November 2019. Analysis of soil samples and plant samples was conducted in the laboratory of Soil Science, Faculty of Agriculture, University of Bengkulu.

The design used in this study is Randomize Complete Block Design (RCBD) one factor is the administration of vermicompost dose with three replays. The level of dosing vermicompost consists of seven levels, namely: $\mathrm{V}_{0}=0$ ton $\mathrm{ha}^{-1}, \mathrm{~V}_{1}=5$ tons ha ${ }^{-1}$, $\mathrm{V}_{2}=10$ tons ha ${ }^{-1}, \mathrm{~V}_{3}=15$ tons ha ${ }^{-1}, \mathrm{~V}_{4}=20$ tons ha ${ }^{-1}$, $\mathrm{V}_{5}=25$ tons ha ${ }^{-1}$, and $\mathrm{V}_{6}=30$ tons ha ${ }^{-1}$. This study was conducted on experimental plots with a size of 3 $\mathrm{m} \times 1 \mathrm{~m}$ and a planting distance of $75 \mathrm{~cm} \times 20 \mathrm{~cm}$ so that 20 plants per tile were obtained. The number of maps used as much as $3 \times 7=21$ maps.

The research began with the creation of vermicompost with the help of the worm Perionyx excavatus. Furthermore, the preparation of planting land is done by clearing the land from growing weeds. Fertilization is done by giving vermicompost by the treatment dose and basic fertilizer half the recommended dose in the form of TSP 150 g plant $^{-1}$, Urea $0.75 \mathrm{~g}$ plant ${ }^{-1}$, and $\mathrm{KCl} 120 \mathrm{~g}$ plant $^{-1}$ using given beside or around the plant. It is intended that the seedlings are not directly mixed with fertilizer, to avoid the seedlings becoming rotten. Fertilizer is given in conjunction with the planting time. Planting is done with a planting distance of $75 \mathrm{~cm} \times 20 \mathrm{~cm}$. Each planting hole is given 1 seed then covered with soil. Maintenance includes watering, embroidery, fertilization, and control of plant-disrupting organisms. A vegetative sampling of plants is performed when the corn plant is about the age of the plant 8-9 weeks. Harvesting is done after there are signs of harvesting characterized by dried corn crops, yellow and dry corncob, shiny and solidifying corn grains, and if pressed hard.

\section{RESULTS AND DISCUSSION}

The research land used is Entisols land that has a soil $\mathrm{pH}$ value of 5.03 which is classified as sour, contains C-organic of $3.34 \%$ which is classified as high, and the $\mathrm{P}$ level available at 6.60 which is classified as low. While the vermicompost used in this study contained C-organic by $9.54 \%$, N-total by $1.31 \%$, P-total by $0.92 \%$, and K-total by $0.30 \%$. The average temperature during the study was $26.300 \mathrm{C}$, the average humidity was $83.35 \%$, the average amount of rainfall was $73.20 \mathrm{~mm}$, and the average number of rainy days was 4.8 days month ${ }^{-1}$.

The results of the statistical analysis of the data collected showed that the dose of vermicompost was manifestly influential $(\mathrm{P} \leq 0.05)$ on soil $\mathrm{pH}$ and dry biomass weight of plants. The dose of vermicompost has an invisible effect $(\mathrm{P}>0.05)$ on soil $\mathrm{P}$ levels, tissue $\mathrm{P}$ levels, dry matter yield, and grains yield.

The vermicompost and soil $\mathrm{pH}$ doses form the positive linear relationship described by the y model $=0.0101 \mathrm{x}+4.8658$ with a determination value $\left(\mathrm{R}^{2}\right)=$ 0.3672 . This relationship model shows that any increase in vermicompost dose from 0 tons of ha- 1 to 30 tons of ha ${ }^{-1}$ will be followed by an increase in soil $\mathrm{pH}$ averaging 0.0101 units. Coefficient of determination $\left(\mathrm{R}^{2}\right)=0.3672$ means that the contribution of vermicompost dose to soil $\mathrm{pH}$ changes averages $37 \%$. The relationship between the two changes is as seen in Figure 1. 


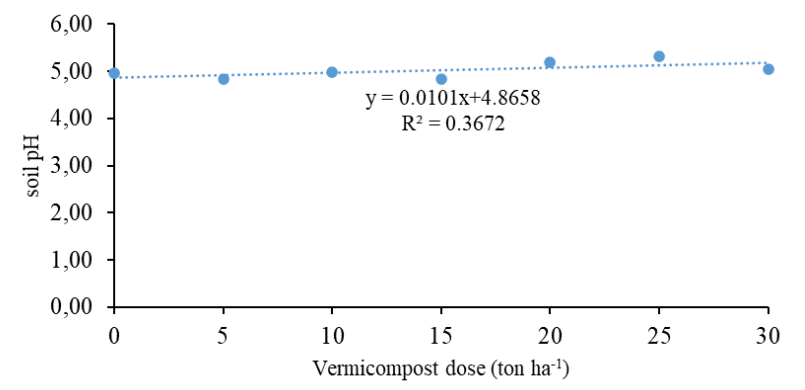

Figure 1. Relationship between vermicompost dose and soil $\mathrm{pH}$

Vermicompost that has been decomposed can release organic compounds, be it organic acids or alkaline cations, which will increase soil pH. According to Hamed et al. (2014), organic acids as a result of decomposition can bind to $\mathrm{H}^{+}$ions as a cause so that soil pH increases. Bayer et al. (2001) and Muktamar et al. (1998) explain that the ups and downs of soil $\mathrm{pH}$ are the functions of $\mathrm{H}+$ and $\mathrm{OH}-$ ions, if the concentration of $\mathrm{H}+$ ions in soil solution rises, then the $\mathrm{pH}$ will go down, and if the concentration of OH-up ions then the $\mathrm{pH}$ will rise. Decomposed organic matter will produce $\mathrm{OH}$ - ions that can neutralize the activity of $\mathrm{H}^{+}$ions. The results of Yuka et al. (2017) showed that vermicompost application was able to increase soil $\mathrm{pH}$ ultisol by up to $20 \%$, even in Setiawan et al. (2015) soil pH increase due to vermicompost application in ultisol reached $23.76 \%$.

While the change of $\mathrm{P}$ level available and tissue $\mathrm{P}$ level dose vermicompost gives an unreal influence $(\mathrm{P}>0.05)$. This is because research is carried out in the dry season so that the availability of groundwater is very low. The soil used for research is Entisol soil that has a sand texture that has a very low water-holding power. In dry conditions, water that can be stored in the soil is also very low to meet the water needs of plants. Decomposition of vermicompost applied into the soil is also disrupted resulting in decreased absorption of $\mathrm{P}$.

Thus soil P levels and tissue P levels at each vermicompost dose tend to differ. Soil $\mathrm{P}$ levels at the application of 20 tons of ha ${ }^{-1}$ tend to be higher compared to other vermicompost doses. While the tissue $\mathrm{P}$ levels at the application of 15 tons $\mathrm{ha}^{-1}$ vermicompost tends to be higher (Table 1).

Vermicompost dose and dry biomass weight form a positive linear relationship with the dry weight described by the equation $\mathrm{y}=2.2757 \mathrm{x}+$ 49.236 with a determination value $\left(R^{2}\right)=0.4685$. Each addition of 1 ton $\mathrm{ha}^{-1}$ dose of vermicompost will be followed by an increase in dry biomass weight on average of $2.2757 \mathrm{~g}$. The determination value $\left(\mathrm{R}^{2}\right)=0.4685$ means that the contribution of vermicompost dose to dry biomass weight averages $47 \%$. The pattern of relationship between vermicompost dose and dry biomass weight is presented in Figure 2.

Table 1. Effect of vermicompost on P level available and $\mathrm{P}$ tissue content

\begin{tabular}{ccc}
\hline $\begin{array}{l}\text { Vermicompost } \\
\text { dose }\left(\text { ton } \mathrm{ha}^{-1}\right)\end{array}$ & $\begin{array}{c}\text { level available } \\
(\mathrm{ppm})\end{array}$ & $\begin{array}{c}\text { tissue P levels } \\
(\%)\end{array}$ \\
\hline 0 & 8.57 & 0.21 \\
5 & 10.65 & 0.20 \\
10 & 14.00 & 0.20 \\
15 & 14.56 & 0.24 \\
20 & 23.00 & 0.19 \\
25 & 17.90 & 0.22 \\
30 & 12.42 & 0.22 \\
\hline
\end{tabular}

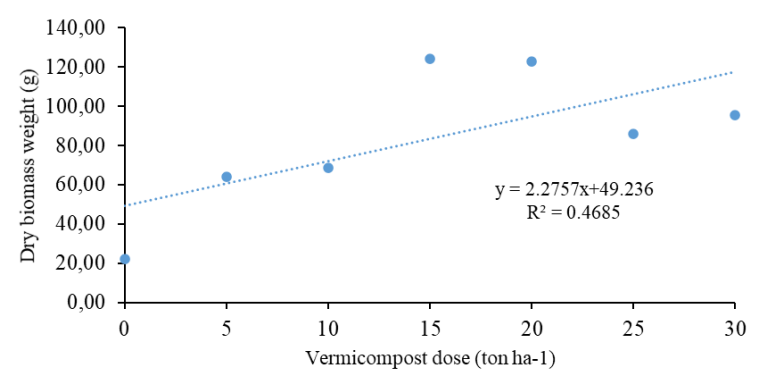

Figure 2. Relationship between vermicompost dose and dry biomass weight

The increase in the dose of vermicompost given will be followed by the increase in the dry biomass weight of corn crops. Vermicompost dose is given the higher the nutrients available to plants so that the absorption is increasing. Adequacy of plant nutrient needs, especially $\mathrm{N}$ will stimulate the increase in plant height, stem diameter, and the formation of new leaves so that the weight of dry biomass increased. According to Lingga \& Marsono (2007) that in the vegetative period corn crops need nitrogen $(\mathrm{N})$ for the formation of root stems and leaves, while in generative times it is necessary for the formation of cobs. Nurdin et al. (2009) added that photosynthesis is influenced by $\mathrm{N}$ levels in the form of organic compounds that are translocated throughout the plant and affect the dry weight of plants

The results of the variant analysis showed that the dose of vermicompost given had an unreal influence on dry matter yield and grains yield. This is because the climatic conditions during the study are less optimum to maize crops less respond to the ver- 
micompost given. The average air temperature during the study was $26.30{ }^{\circ} \mathrm{C}$, the average humidity was $83.35 \%$, the average amount of rainfall was $73.20 \mathrm{~mm}$, and the average number of rainy days was 4.8 days month ${ }^{-1}$. Based on the data, it appears that corn crops during the study experienced water shortages. According to Barnito (2009) that the optimum rainfall for corn crops is ranging from $100-125$ $\mathrm{mm}_{\mathrm{month}}{ }^{-1}$.

The results showed that although it showed unreal differences between dry matter yield and grains yield at each dose vermicompost tends to differ. The provision of 15 tons of vermicompost ha ${ }^{-1}$ produces dry matter yield and grains yield tends to be heavier i.e. $223.89 \mathrm{~g}$ and $35.82 \mathrm{~g}$ (Table 2) respectively.

Table 2. Effect of vermicompost on dry matter yield and grains yield

\begin{tabular}{|c|c|c|}
\hline $\begin{array}{l}\text { Vermicompost } \\
\text { dose (ton } \mathrm{ha}^{-1} \text { ) }\end{array}$ & $\begin{array}{l}\text { Dry matter yield } \\
(\mathrm{g})\end{array}$ & $\begin{array}{l}\text { Grains yield } \\
\text { (g) }\end{array}$ \\
\hline 0 & 170 & 31.88 \\
\hline 5 & 183.61 & 31.27 \\
\hline 10 & 196.11 & 34.26 \\
\hline 15 & 223.89 & 35.82 \\
\hline 20 & 210 & 35.09 \\
\hline 25 & 213.33 & 34.79 \\
\hline 30 & 215.56 & 35.27 \\
\hline
\end{tabular}

\section{CONCLUSION}

Based on the results of the study, it can be concluded that there is no optimum dose of vermicompost to soil P levels, tissue P levels as well as corn growth and yield. Increased dose vermicompost up to 30 tons ha-1 followed by increased $\mathrm{pH}$ value of soil and dry biomass weight corn crops.

\section{References}

Badan Pusat Statistik. (2015). Produksi Padi, Jagung dan Kedelai (Angka Sementara 2014). Berita Resmi Statistik. No. 25/03/21 Th.X.

Barnito, N. (2009). Budidaya Tanaman Jagung. Suka Abadi, Yogyakarta.

Bayer, C, Martin-Neto, L.P., Mielniczuk, J., Pillon, C.N. \& Sangoi, L. (2001). Changes in Soil Organic Matter Fractions Under Subtropical No-Till Cropping Systems. Soil Sci. Soc. Am. J., 65 (1), 1473-1478.

Dou, H. (2004). Effect of Cutting Application on Tomat to Growth and Yield. 5-15 p.

Fox, R.H., Roth, G.W., Iversen, K.V. \& Piekielek, W.P. (1998). Soil and tissue nitrate tests com- pared for predicting soil nitrogen availability to corn. Agron. J., 81, 971-974.

Gaol, S.K.L., Hanum, H.\& Sitanggang, G. (2014). Pemberian zeolit dan pupuk kalium untuk meningkatkan ketersediaan hara $\mathrm{K}$ dan pertumbuhan kedelai di Entisol.Jurnal Online Agroekoteknologi, 2(3), $1151-1159$

Hadijah, A. D. (2009). Identifikasi kinerja usahatani dan pemasaran jagung di Nusa Tenggara Barat. Prosiding Seminar Nasional Serealia. ISBN:978-979-8940-27-948.

Hamed, M.H., Desoky., A.M . Ghallab., Faragallah, M.A. (2014). Effect of incubation periods and some organic materials on phosphorus forms In calcareous soils. International. Journal of Technology Enhancements and Emerging Engineering Research, 2(6), 23474289

Idris, Y.A \& Ali, S.A.M. (2015). Response of maize (Zea mays L.) to sodium chloride concentrations at early growth stages. International Journal of Agronomy and Agricultural Research. 6(4), 68-74.

Kurniati, D. (2012). Analisis risiko produksi dan faktor-faktor yang mempengaruhinya pada usahatani jagung (Zea mays L.) di Kecamatan Mempawah Hulu Kabupaten Landak. Jurnal Sosial Ekonomi Pertanian, 1(3), 60 - 68.

Kusnadi, M.H. (2000). Potensi Pupuk Organik Kascing dan Pupuk Hayati Cendawan Mikoriza dalam Pertanian Organik. Prosiding Seminar Nasional Pertanian Organik. Fakultas Pertanian Universitas Pembangunan Nasional Veteran.Yogyakarta.

Lingga, P. \& Marsono. (2007). Petunjuk Penggunaan Pupuk. Penebar Swadaya, Jakarta.

Mulat, T. (2005). Kascing Pupuk Organik Berkualitas. Agromedia Pustaka, Jakarta.

Mulyani, A., Rachman, A. \& Dairah, A. (2010). Penyebaran Lahan Masa, Potensi dan Ketersediaannya untuk Pembangunan Pertanian. Prosiding Simposium Nasional Pendayagunaan Tanah Masam. Pusat Penelitian dan Pengembangan Tanah dan Agroklimat. Bogor, Bogor.

Nurdin, C.M. Kusharto, Tanziha, I. \& M. Januwati. (2009). Kandungan klorofil berbagai jenis daun tanaman dan $\mathrm{Cu}$-turunan klorofil serta karakteristik fisiko-kimianya, 4(1), 13-19

Pusat Penelitian Tanah dan Agroklimat. (2006). Atlas Sumberdaya Tanah Eksplorasi Indonesia Skala 1 : 1.000.000. Puslittanak, Badan Litbang Pertanian, Bogor.

Riwandi, Handajaningsih, M., Hasanudin \& Munawar, A. (2015). Soil quality improvement using compost and its effects on organik-corn production. Journal of Tropical Soils, 20(1), 11-19. 
Setiawan, I.G.P., Niswati, A., Hendarto, K. \& Yusnaini, S. (2015). Pengaruh dosis vermikompos terhadap pertumbuhan tanaman pakcoy (Brassica rapa L.) dan perubahan beberapa sifat kimia tanah Ultisol Taman Bogo. Jurnal Agrotek Tropika, 3(1), 170-173.

Utami, S.N.H. \& Handayani, S. (2003). Sifat kimia Entisol pada sistem pertanian organik Ilmu Pertanian, (10)2, 63-69.
Yuka, M.F., Niswati, A. \& Hendarto, K. (2017). Pengaruh dosis vermikompos terhadap pertumbuhan produksi dan serapan N \& P tanaman mentimun (Cucumis sativus L.) pada media asal dua kedalaman tanah Ultisol. Jurnal Penelitian Pertanian Terapan, 17(2), 117-123. 